\title{
Briefing: Design and construction of Canary Wharf temporary floating road, London, UK
}

1 Cliff Ohl BS(OE), DPhil, CEng, MICE

Principal Engineer, Royal HaskoningDHV, Newcastle upon Tyne, UK (corresponding author: cliff.ohl@rhdhv.com)

2 Benjamin Radcliffe MEng(Hons)

Graduate Engineer, Royal HaskoningDHV, Newcastle upon Tyne, UK
3 Harvey Richardson BSC

Project/Fabrication Manager, VolkerBrooks Ltd, Morecambe, UK

4 Ashley Handley-Collins BSC

Assistant Project Manager, Canary Wharf Contractors Ltd, London, UK
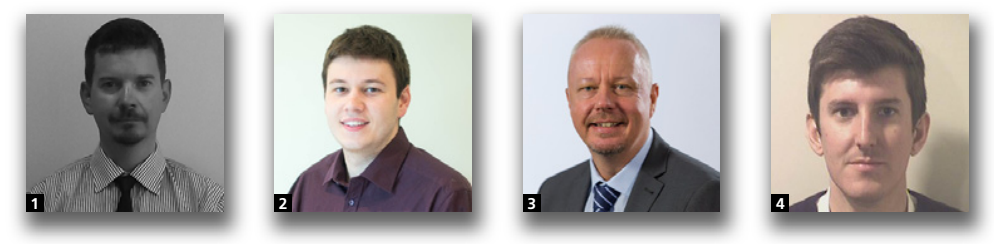

The Canary Wharf floating road was constructed to provide access for articulated lorries to a congested construction site, the Newfoundland project in central London. The $80 \mathrm{~m} \times 15 \mathrm{~m}$ floating road incorporates a modular steel roadway deck spanning over 81 modular Linkflote pontoons. Linkspan ramps for vehicle access and a pontoon lateral restraint system are designed to minimise impact on the existing dock wall (grade II listed) by connecting to the Newfoundland Building's ground-floor structure (under construction). With constructability a principal issue, all structural components were designed as modular steel assemblies, transported using standard road vehicles and assembled on site. A structural model, compatible with building information modelling, including all components and interfaces, was produced to develop the design, produce fabrication and installation drawings and ensure integration with the permanent works. The floating road provides an essential platform for transport, materials handling and storage for the Newfoundland project.

\section{Introduction}

The Canary Wharf floating road was constructed to provide access for articulated lorries (heavy goods vehicles (HGVs)) to a congested construction site in central London, the Newfoundland project (CWG, 2017) (Figure 1). The Newfoundland project occupies the majority of the landside construction area at the western end of Canary Wharf's Middle Dock (formerly the West India Export Dock), and the floating road would be located within the dock to utilise the significant waterside area.

Canary Wharf Contractors Limited and VolkerBrooks conceived the floating road as a pontoon-supported road suitable for up to three road-going HGVs, approximately $16.5 \mathrm{~m}$ long articulated lorries with a minimum turning radius of the order of $12 \mathrm{~m}$.

A requirement for two notional lanes was identified, with one lane for vehicles to park and unload material and the second lane to allow vehicles to pass. Starting from the north ramp linkspan access, vehicles would move from north to south along the pontoon and exit through the south ramp linkspan. As access from the River Thames to the dock is not adequate for construction barges of the size required, a modular pontoon solution was adopted with similar modular requirements for linkspan and roadway structures for transport and site assembly.

With these as the principal design requirements, contractor VolkerBrooks and engineer Royal HaskoningDHV commenced design, fabrication and installation of the floating road.

\section{Concept design}

Roadway and ramp lateral dimensions and orientation were initially based on guidance for roll-on/roll-off maritime terminals (BS 6349-8-2007 (BSI, 2007)) and standard HGV turning area requirements (Littlefield, 2008), and subsequently confirmed using vehicle-swept path analysis software. This resulted in a $10 \mathrm{~m}$ wide trafficable area on the pontoon, with the north ramp geometry allowing vehicles to start turning while on the ramp and complete the turn on the pontoon roadway deck.

In accordance with BS 6349-6 (BSI, 1989) and the work of Hathrell (1968), buoyancy and stability calculations identified the requirement for an $80 \mathrm{~m} \times 15 \mathrm{~m} \times 1.23 \mathrm{~m}$ deep pontoon comprising 81 Linkflote modular pontoons (VolkerBrooks, 2017) to support the vehicles, roadway and dockside ramp bearings. 


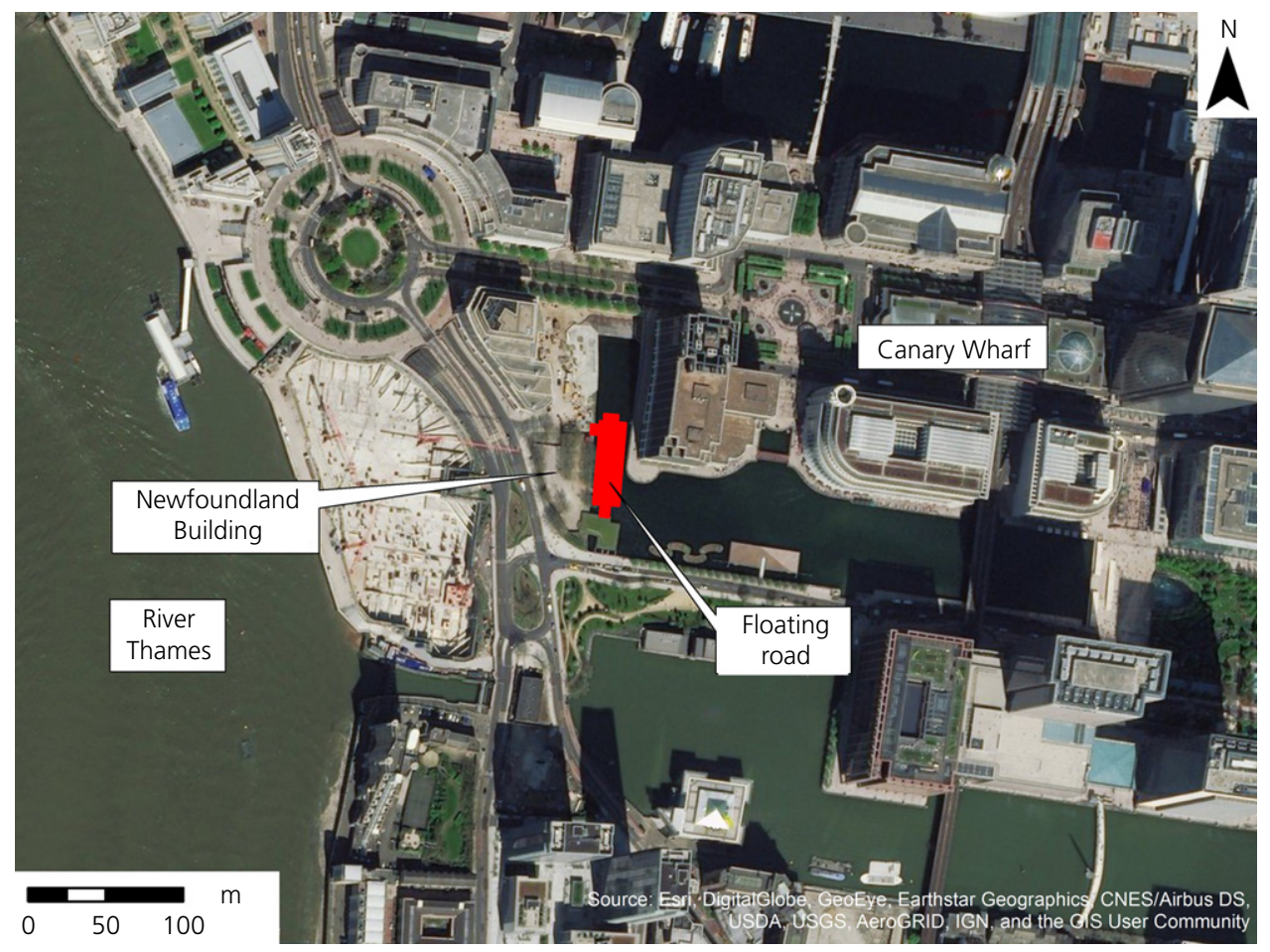

Figure 1. Project location at Canary Wharf, London

Given the relatively long pontoon length (i.e. high spanto-depth ratio), structural analyses were conducted to assess internal forces (bending moment and shear) resulting from vehicles and linkspan ramp loads. Several pontoon configuration options were analysed, and an articulated hinge was introduced near to the pontoon midpoint to significantly reduce the bending moments developing within the pontoon.

Similarly, given the imposed loading requirements (including high axle and wheel loading due to HGVs) as provided in BS EN 1991-2 (BSI, 2002), a modular steel roadway deck was conceived to span over the Linkflote pontoons and transfer vehicle loads to the gunwale strongpoints at the pontoon sides.

Geometry and vertical transitions for the two linkspan access ramps were based on guidance from BS 6349-8 (BSI, 2007) to suit HGVs. As Canary Wharf's Middle Dock is an impounded basin with regulated water levels and relatively small fetch length, an appropriate range of dock water levels and pontoon freeboards was considered to ensure adequate linkspan ramp slopes and transitions as based on records of dock water levels and operational practices.

Given the relatively sheltered, impounded location for the development, hydraulic actions/loads (i.e. due to waves and currents) were assessed as non-governing in comparison to other imposed loads (e.g. due to HGVs).

\section{Detailed design}

With constructability a principal concern, the structural components were designed in accordance with BSI (2006) to provide relatively lightweight, modular steel assemblies that would be transported using standard road vehicles and assembled without the need for site welding. Similarly, material selection focused principally on rectangular hollow section (RHS) members to reduce requirements for internal bracing and associated additional fabrication effort, for example welded connections.

\subsection{Building information modelling (BIM)}

A BIM-compatible structural model, including all components and interfaces, was produced using Tekla Structures software (Trimble, 2017), as illustrated in Figure 2. This allowed development of the design and efficient production of fabrication and installation drawings, while ensuring integration with the permanent works. In addition, the three-dimensional (3D) steelwork model allowed more efficient fabrication and level 2 BIM compliance allowed sharing of the model between client and contractor in a collaborative manner, with one common source of information. 


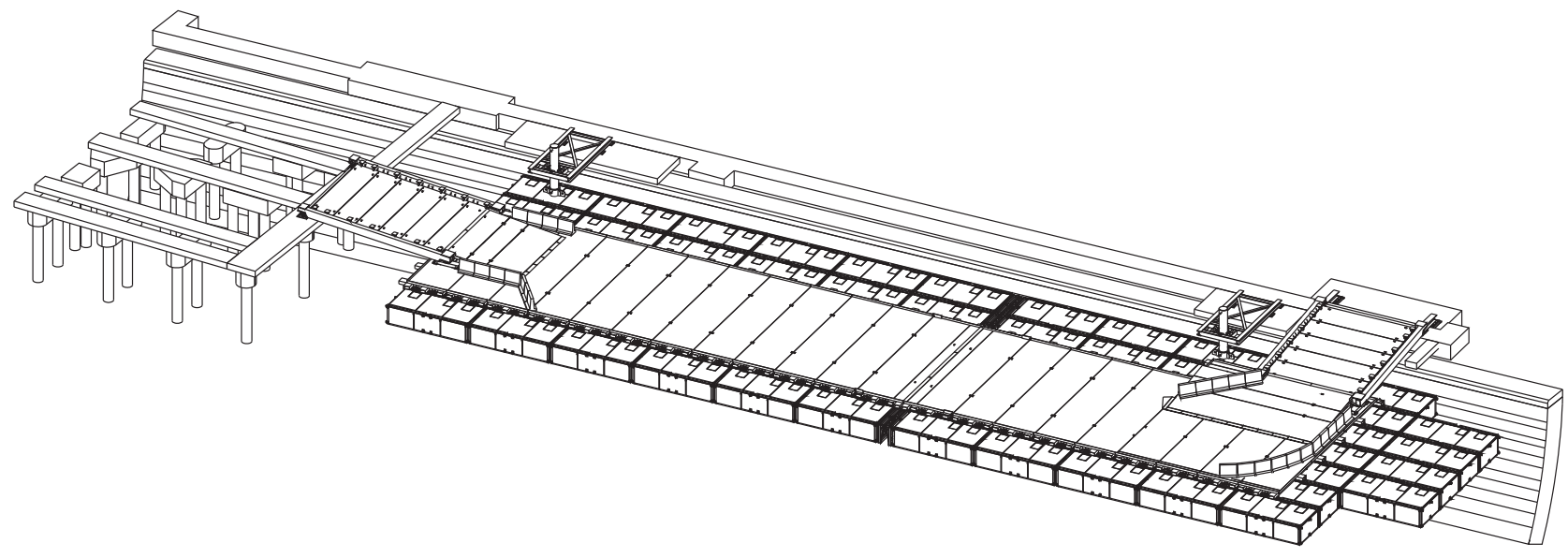

Figure 2. Tekla BIM model - complete structure, 3D isometric mode

\subsection{Roadway deck}

The modular roadway unit structure was based on an orthotropic deck/grillage of RHS members with a steel plate welded on to carry vertical loads and distribute lateral and longitudinal loads as a diaphragm.

The structural concept design for the roadway deck units principally utilised RHS supporting members with steel plates welded to form the trafficable deck. The RHS sections were orientated with the longest edge horizontal to reduce structural depth and accommodate the lateral traffic forces due to braking and acceleration. RHSs were selected due to the relatively low structural depth, higher minor axis strength and higher lateral stability relative to equivalent open sections. As such, the resulting structures would facilitate lower pontoon roadway levels and resistance to lateral loads.

To transfer vertical load into the Linkflote gunwales (strongpoints at the side of the modular pontoons), elastomeric plain bearing pads were bonded to the underside of the roadway deck units. In addition, ISO (International Organization for Standardization) standard twist locks (i.e. as used for shipping containers) were welded to the road deck units to provide lateral restraint when secured.

Proprietary road deck surfacing products were selected to provide surface skid resistance as appropriate for $\mathrm{HGV}$ vehicle traffic and durability based on bond quality to the steel deck plate.

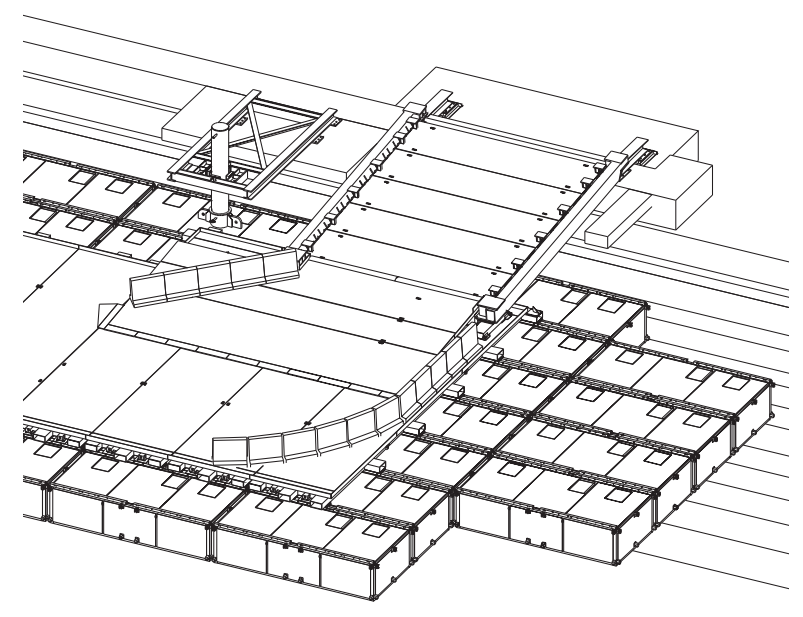

(a)

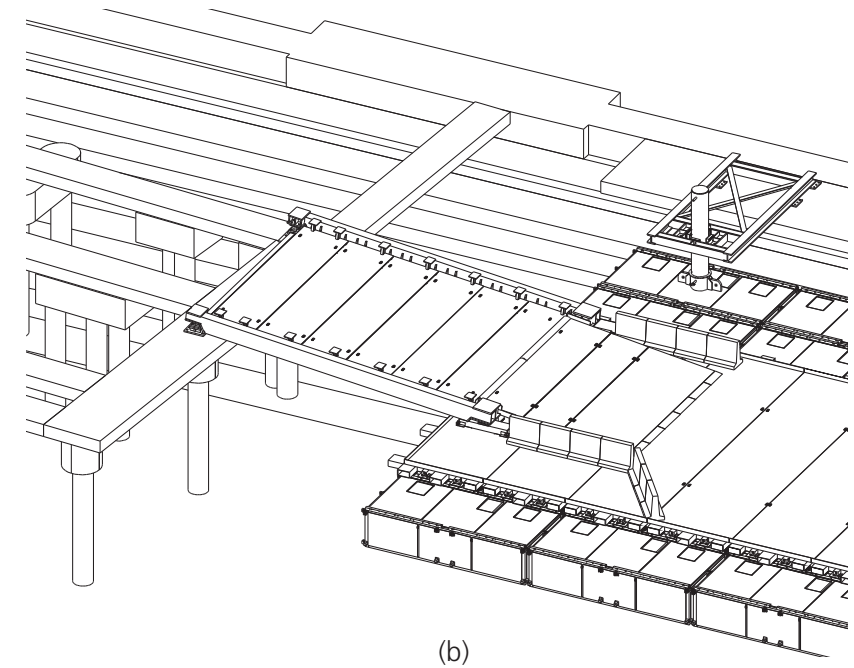

Figure 3. Tekla BIM model: extracts of (a) north ramp and (b) south ramp and lateral restraints 
Maritime Engineering

Volume 170 Issue MA3+4
Briefing: Design and construction of Canary Wharf temporary floating road, London, UK

Ohl, Radcliffe, Richardson and

Handley-Collins

\subsection{Linkspan ramps}

As illustrated in Figures 3(a) and 3(b), linkspan ramps for vehicle access were designed to minimise impacts on the existing dock wall (grade II listed) by connecting to the Newfoundland Building's ground-floor structure (under construction).

Linkspan ramp structural concepts were developed as through bridges composed of longitudinal RHS edge beams with steel plates welded to transverse RHS beams spanning in between.
Similar to the modular roadway deck, RHS members were selected for their low structural depth, high minor axis strength and high lateral stability. To accommodate pontoon and roadway deck movement (vertical, horizontal and rotational), the ramp was conceived to be flexible with respect to torsion, with pinned connections between longitudinal and transverse members to allow rotation.

Spanning over the existing grade II listed dock wall to the pontoon, the north ramp is perpendicular to the pontoon.

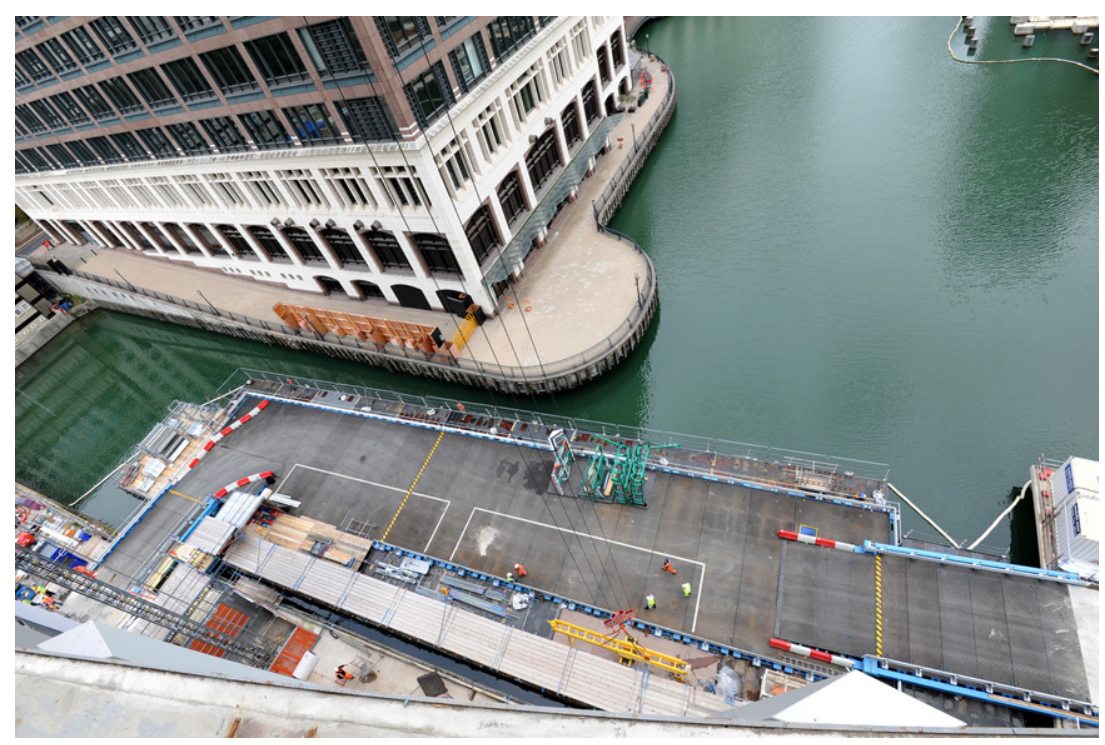

(a)

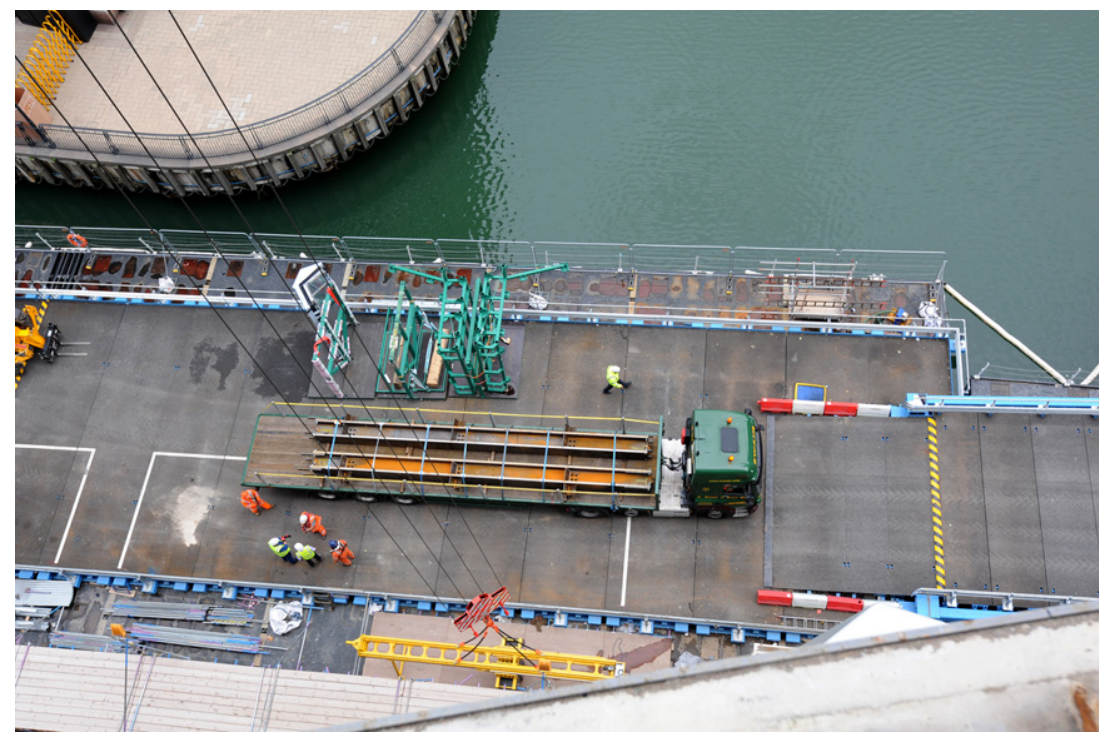

(b)

Figure 4. Photographs from above showing (a) full road deck and (b) southern end 
Briefing: Design and construction of Canary Wharf temporary floating road, London, UK

Ohl, Radcliffe, Richardson and

Handley-Collins
The north ramp abutment/bankseat was supported on the newly constructed ground-floor slab and perimeter secant pile wall capping beam of the Newfoundland Building.

The linkspan bearings (Ekspan, 2017) on the abutment support vertical loads and resist lateral loads but allow vertical rotation (thus accommodating variation in dock water level and pontoon freeboard). Spanning over the existing grade II listed dock wall, the linkspan ramp bears onto spherical bearings on the pontoon roadway deck, allowing for possible rotation and translation of the floating structure. As such, the ramp longitudinal edge beams are simply supported between the link bearings at the landward end and spherical bearings on the pontoon, with transverse beams and steel deck plans as required.

With a similar bearing plan layout, the south ramp abutment was founded on a suspended deck structure (precast reinforced concrete deck on concrete piles) at the southern end of the site, with the linkspan ramp extending onto the pontoon roadway deck.

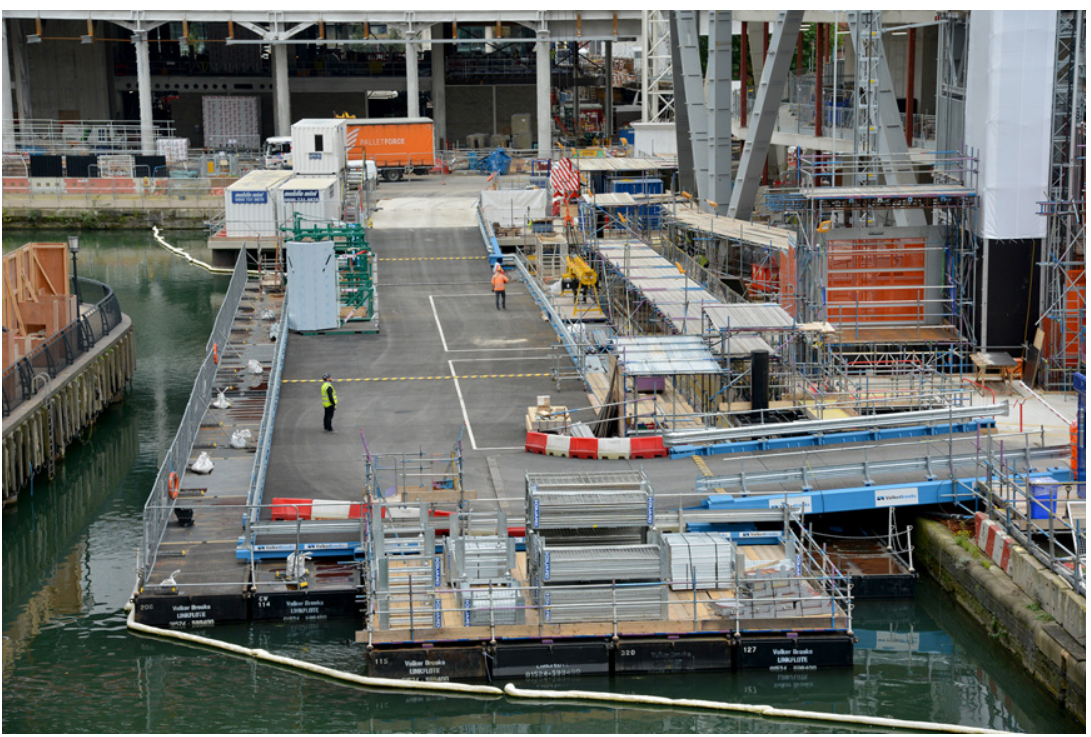

(a)

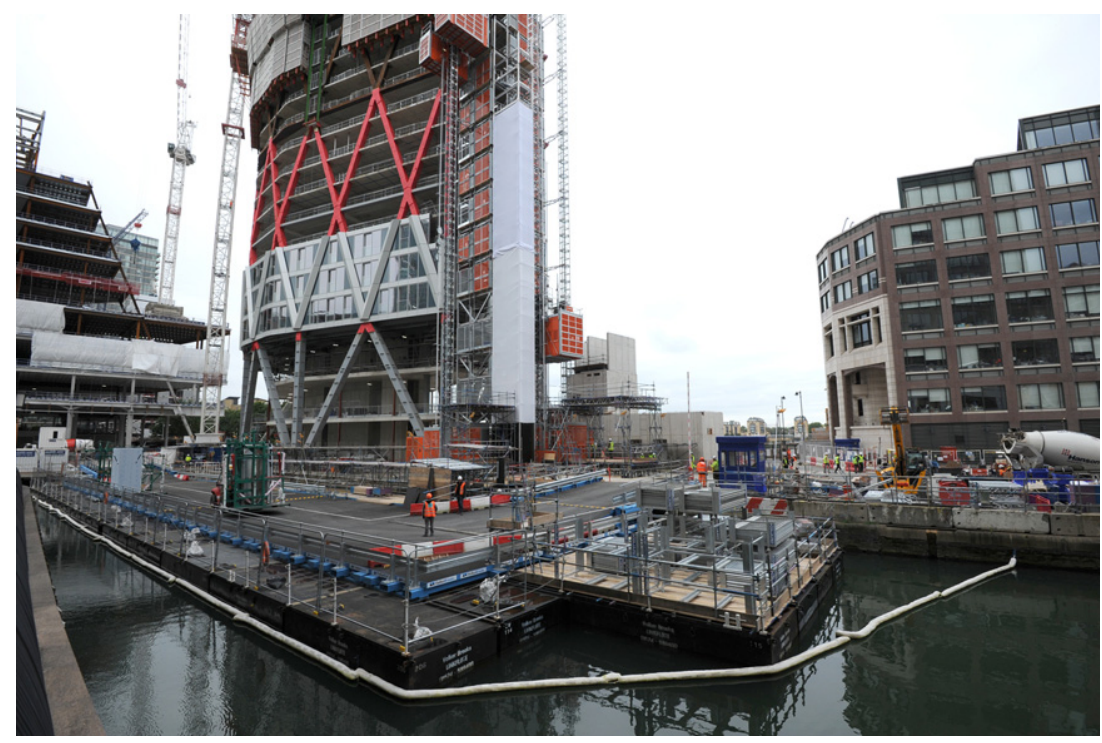

(b)

Figure 5. Photographs from ground level: (a) from northern end and (b) towards the Newfoundland building (under construction) 


\subsection{Pontoon restraints}

Lateral loads on the pontoon include vehicle braking and acceleration, as defined in BS EN 1991-2 (BSI, 2002), and a pontoon lateral restraint system was developed to transfer lateral loads into the Newfoundland Building ground-floor slab, as illustrated in Figures 3(a) and 3(b). The restraint system comprised tubular steel spuds and corresponding support frames at both the northern and southern end of the pontoons.

The spuds were supported vertically on the pontoon within larger diameter steel turrets housed within a standard Linkflote pontoon unit and based on the existing standard Linkflote spud system. These turrets provided moment restraint to maintain spud pile vertical alignment. In addition, plates welded beneath the turrets supported the spuds vertically on the pontoon and ensured that the spuds would not extend to the grade II listed dock floor/wall.

To provide lateral restraint, lateral support frames extended from the ground-floor slab of the Newfoundland Building over the pontoon to the spuds. The lightweight welded steel frames comprised open steel sections (channels and angles) supporting a collar over the spuds, with low-friction ultra-high-molecular weight polyethylene pads bearing onto the spuds. Lateral loads on the pontoon (e.g. from vehicle braking/acceleration, wind etc.) are thereby transferred through the spuds, to the restraint frames and into the Newfoundland ground-floor slab.

\section{Fabrication, installation and commissioning}

All drawings (including general arrangement and fabrication), schedules and input data for the computer numerical control machines were produced directly from the BIM-compatible model. This greatly increased accuracy and speed of steelwork fabrication and was essential in meeting the programme dates. In addition, Tekla's clash check system was used to avoid complications (and expensive errors) during the manufacturing stage and on site after installation, for example avoiding clashes at the interfaces between linkspan ramp bearings and landside structures under construction by Canary Wharf Contractors Limited.

As illustrated in Figures 4 and 5, VolkerBrooks completed installation and commissioning of the floating road in September 2017 and will maintain this temporary floating structure (with regular site inspections) for an estimated duration of 2 years before decommissioning.

\section{Conclusions}

Given the logistical challenges posed by construction on a congested site, modular floating structures provided a novel logistics solution when land area was limited but waterside dock area was available for use. For this project, BIM software was used to manage the design, fabrication and installation processes, with modular structural components developed to address the principal concerns of constructability, flexibility and site interfaces. Commissioned in 2017, the floating road will provide an essential temporary platform for transport, materials handling and storage for the Newfoundland project for several years.

\section{Acknowledgements}

In addition to the broad range of staff within Canary Wharf Contractors, VolkerBrooks and Royal HaskoningDHV who supported the project, the authors acknowledge the late Steve Cross BSc(Hons), CEng, MICE, whose enthusiasm and competence in the field of temporary, modular floating structures were inspirational.

\section{REFERENCES}

BSI (1989) BS 6349-6:1989: Code of practice for maritime structures, design of inshore moorings and floating structures. BSI, London, UK.

BSI (2002) BS EN 1991-2:2002: Eurocode 1: Actions on structures part 2: traffic loads on bridges. BSI, London, UK.

BSI (2006) BS EN 1993-2:2006: Eurocode 3: Design of steel structures - part 2: steel bridges. BSI, London, UK.

BSI (2007) BS 6349-8:2007: Maritime structures, code of practice for the design of Ro-Ro ramps, linkspans and walkways. BSI, London, UK.

CWG (Canary Wharf Group PIc) (2017) http://group.canarywharf.com (accessed 01/11/2017).

Ekspan (2017) http://www.ekspan.com (accessed 01/11/2017).

Hathrell JAE (1968) Bailey and Uniflote Handbook, 3rd edn. Acrow Press, London, UK.

Littlefield D (ed.) (2008) Metric Handbook, 3rd edn. Architectural Press, Oxford, UK.

Trimble (2017) http://www.tekla.com (accessed 01/11/2017).

VolkerBrooks (2017) http://www.volkerbrooks.co.uk (accessed 01/11/2017).

\section{How can you contribute?}

To discuss this briefing, please email up to 500 words to the editor at journals@ice.org.uk. Your contribution will be forwarded to the author(s) for a reply and, if considered appropriate by the editorial board, it will be published as discussion in a future issue of the journal.

Proceedings journals rely entirely on contributions from the civil engineering profession (and allied disciplines). Information about how to submit your paper online is available at www.icevirtuallibrary.com/page/authors, where you will also find detailed author guidelines. 